\title{
OVERDRILLED WINTER-GROWING ANNUAL GRASS TO SUPPLEMENT LUCERNE
}

\author{
E. W. VARTHA
}

Grasslands Division, DSIR, Lincoln

\section{Summary}

On light droughty soils in Canterbury, 'Grasslands Tama' westerwolds ryegrass when overdrilled into lucerne has produced between 1,200 and $5,200 \mathrm{~kg} / \mathrm{ha}$ of dry herbage, in part supplementary and in part complementary to lucerne growth. Factors affecting growth of the overdrilled ryegrass, such as time of sowing, use of nitrogen at overdrilling and in mid-winter, and of grazing in mid-winter and early spring, are illustrated. On heavier moisture-retentive soils, autumn growth of lucerne reduces establishment of overdrilled grass. At high stocking rates on all-lucerne farms on light lands Tama ryegrass can provide high quality greenfeed prior to spring growth of lucerne and thus assist management to better equate feed supply with stock needs.

Where Tama ryegrass is sown in cultivated soil, herbage yields far exceed those obtained where it is overdrilled into lucerne. Systems analysis may aid the development of a sound choice for use of the above grass with lucerne. Because ruminants are inefficient converters of leaf protein to animal protein the use is suggested of Lucerne overdrilled with grass for producing leaf-protein concentrate for monogastric animal feeding and partial-protein-extracted residue for feeding ruminants.

\section{INTRODUCTION}

IN CaNTerbury there have been considerable changes in farm management practices with lucerne (Medicago sativa Link.). On light lands pure lucerne is used for grazing; on heavier lands and also on irrigated light lands in the Ashburton County, lucerne is being grown as a process crop for poultry food. Previously lucerne was grown primarily for hay.

Eyre soils on the "Ashley Dene" oroperty of Lincoln College are typical of light lands without irrigation. Annual production from experimental plots of lucerne under intermittent grazing has varied from $8,360 \mathrm{~kg} / \mathrm{ha}$ of dry herbage to $3,180 \mathrm{~kg} / \mathrm{ha}$ (late C. E. Tversen, pers. comm.; E. W. Vartha, unpublished data). Annual lucerne yield on non-irrigated light lands shows considerable variation according to amounts of summer and 
autumn rainfall (O'Connor et al., 1968). On Lismore soils (light lands) in 88 comparisons over 6 years, the average dry matter yield of lucerne without irrigation was $7,350 \mathrm{~kg} / \mathrm{ha}$ and with irrigation was $18,850 \mathrm{~kg} / \mathrm{ha}$ (Dept of Agriculture N.Z. Annual Report, Research Division, 1969-70).

Wakanui soils at Lincoin are typical of medium-heavy lands. Annual production from experimental plots of lucerne under intermittent grazing has varied from $14,110 \mathrm{~kg} / \mathrm{ha}$ of dry herbage to $27,220 \mathrm{~kg} / \mathrm{ha}$ (O'Connor et al., 1968; Vartha, unpubl. data). In 1970-71 seasons, irrigation increased yield of lucerne cut at 5 -week intervals from 14,320 to $19,770 \mathrm{~kg} / \mathrm{ha}$ of dry matter (Vartha, 1971).

On both light and heavy lands, lucerne yields in cool season are negligible relative to those in warm season. This paper dis. cusses supplementation of "warm-season" growing lucerne with "cool-season" growing 'Grasslands Tama' westerwolds ryegrass, introduced by overdrilling in autumn.

\section{LIG HT LANDS}

The all-lucerne farmlet on "Ashley Dene" property of Lincoln College has shown the manner in which this legume can be used in a fat-lamb farming enterprise carrying up to 20 ewes/ha. If normal lambing time for light land was adhered to, early spring is a critical period because of the lack of high quality feed for ewes pre- and post-parturition. Thus, lambing has had to be delayed to better fit the pattern of lucerne growth. In recent years, early summer and autumn droughts have created problems in providing sufficient feed at high stocking rates when lucerne has been ploughed for supplementary winter-cropping as part of the lucerne renewal programme. Also there has been no opportunity to make hay. Improved grazing management and the use of weed-killers are extending the life of the lucerne stands beyond that previously experienced in light land practices, so that alternative methods of supplementary feeding not linked with lucerne renewal are needed. This may be done by overdrilling lucerne with a "cool-season" grass. What has been achieved with this technique.?

Grasslands Division's first experience with the technique was in the favourable moist autumn of 1966. Subsequent measurements showed that annual yield of dry, herbage from a six-year-old, deteriorated stand of lucerne was: lucerne $5,120 \mathrm{~kg} / \mathrm{ha}$, Tama ryegrass $5,180 \mathrm{~kg} / \mathrm{ha}$, and other species $1,270 \mathrm{~kg} / \mathrm{ha}$ (Vartha, 
OVERDRILLED GRASS WITH LUCERNE

TABLE 1: WAIRAU LUCERNE ON EYRE SOIL OVERDRILLED WITH 'GRASSLANDS TAMA' WESTERWOLDS RYEGRASS

(Annual dry herbage yield $-\mathrm{kg} / \mathrm{ha}$ )

\begin{tabular}{|c|c|c|c|c|c|c|}
\hline & & $\begin{array}{c}\text { Cool } \\
\text { Season }\end{array}$ & $\begin{array}{c}\text { Warm } \\
\text { Season }\end{array}$ & $\begin{array}{c}\text { Annual } \\
\text { To ta! }\end{array}$ & $\begin{array}{c}\text { Annual } \\
\text { All Species }\end{array}$ & $\begin{array}{l}\% \text { Tamo } \\
\text { Con- } \\
\text { tribution }\end{array}$ \\
\hline \multicolumn{7}{|l|}{ 1968: } \\
\hline Lucerne & & 1,080 & 2,420 & 3,500 ) & & \\
\hline Tama & & 730 & 480 & 1,210 & $5,570 \pm 204$ & 21 \\
\hline Unsown & & 590 & 270 & 860 & & \\
\hline \multicolumn{7}{|l|}{ 1969: } \\
\hline Lucerne & & 660 & 770 & & & \\
\hline Tama & $\ldots$ & 920 & 570 & 1,490 & $3,180 \pm 54$ & 47 \\
\hline Unsown & $\ldots$ & 230 & 30 & 1.498 & & \\
\hline \multicolumn{7}{|l|}{$1970^{*}:$} \\
\hline Lucerne & & 1,340 & 1,410 & 2,7501 & & \\
\hline Tama & $\ldots$ & 810 & 600 & $1,410 \mid\}$ & $4,930 \pm 282$ & 29 \\
\hline Unsown & $\ldots$ & 530 & 240 & 770 & & \\
\hline \multicolumn{7}{|l|}{ 1971: } \\
\hline Lucerne & & 310 & & & & \\
\hline Tama & & 1,010 & & & & \\
\hline Unsown & & 240 & & & & \\
\hline
\end{tabular}

*Not full warm season because accidentally grazed,

1967). In 1968-71, experiments were conducted on a different stand of lucerne (cv. Wairau) which was 2 years old when first overdrilled (Table 1). Cool season refers to the period from the time of overdrilling in March to the end of August, warm season to the remainder of the year. Cultural practices were varied and are detailed separately. Data for pure lucerne are not shown, but total dry herbage yields in $\mathbf{1 9 6 8}$ were similar and in 1969. approximately $500 \mathrm{~kg} / \mathrm{ha}$ less than where lucerne had been overdrilled with "cool-season" annual grass.

\section{Time OF Sowing}

As a general rule, it has been observed that overdrilled Tama ryegrass must be well established before the cool season if it is to be satisfactorily productive prior to September. The favourable wet autumn of 1966 facilitated good establishment of Tama, which subsequently gave a cool-season yield of dry herbage of $1,810 \mathrm{~kg} / \mathrm{ha}$. In the subsequent experiments, delayed establishment in dry autumn weather led to low cod-season yield. The 
aim has been to overdrill about the beginning of March, Comparison with later sowing dates in 1969 (April 22) and 1970 (March 30) is shown in Table 2. There was no significant effect of time of sowing in 1969, when rainfall to the date of later sowing was only $25 \mathrm{~mm}$ : $88 \mathrm{~mm}$ of rain fell in the succeeding month and mild winter temperatures were experienced.

TABLE 2: WAIRAU LUCERNE ON EYRE SOIL OVERDRILLED AT DIFFERENT TIMES WITH 'GRASSLANDS TAMA' WESTERWOLDS RYEGRASS

\begin{tabular}{|c|c|c|c|c|c|c|c|}
\hline & & & & Lucerne & Tama & Unsown & Total \\
\hline \multicolumn{8}{|l|}{ 1969: } \\
\hline Early & March & & & 1,400 & 1,550 & 290 & 3,240 \\
\hline Later & $\ldots$ & $\ldots$ & $\ldots$ & 1,470 & 1,440 & 210 & 3,120 \\
\hline \multicolumn{8}{|l|}{ 1970: } \\
\hline Early & March & . & $\ldots$ & 2,660 & 2.130 & 750 & 5,540 \\
\hline Later & & $\ldots$ & . & 2,850 & 690 & 800 & 4,340 \\
\hline \multicolumn{8}{|c|}{ d $0.05-443$} \\
\hline
\end{tabular}

Nitrogen AT Sowing

In earlier work, Vartha (1967) showed that light cultivation of a lucerne sward, prior to overdrilling with a grass, increased the early establishment of the grass, and this was attributed to increased mineralization of soil nitrogen. In subsequent experiments (Table 3) nitrogen applied at overdrilling, without prior surface cultivation, had no significant effect on grass growth in two out of three years.

TABLE 3: WAIRAU LUCERNE ON EYRE SOIL OVERDRILLED WITH 'GRASSLANDS TAMA' WESTERWOLDS RYEGRASS AND

GIVEN TWO LEVELS OF NITROGEN WHEN OVERDRILLED

(Annual dry herbage yield $-\mathrm{kg} / \mathrm{hai}$ )

\begin{tabular}{|c|c|c|c|c|c|c|}
\hline & & & Lucerne & Tama & Unsown & Total \\
\hline \multicolumn{7}{|l|}{ 1968: } \\
\hline 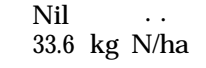 & $\cdots$ & & $\begin{array}{l}3,690 \\
3,310\end{array}$ & $\begin{array}{l}1,310 \\
1,120\end{array}$ & $\begin{array}{r}1,020 \\
580\end{array}$ & $\begin{array}{l}6,020 \\
5,010\end{array}$ \\
\hline 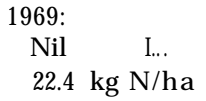 & $\cdots$ & & $\begin{array}{l}\mathrm{i}, 520 \\
1,350\end{array}$ & $\begin{array}{l}1,090 \\
1,900\end{array}$ & $\begin{array}{l}270 \\
24.0\end{array}$ & $\begin{array}{l}2,880 \\
3,490\end{array}$ \\
\hline $\begin{array}{l}\text { 1970: } \\
11.2 \mathrm{~kg} \mathrm{~N} / \mathrm{ha} \\
33.6 \mathrm{~kg} \mathrm{~N} / \mathrm{ha}\end{array}$ & & '"' & $\begin{array}{l}d 0.05 \\
2,620 \\
2,890\end{array}$ & $\begin{array}{l}5 \\
1,410 \\
1,420\end{array}$ & $\begin{array}{l}760 \\
780\end{array}$ & $\begin{array}{l}4,790 \\
5,090\end{array}$ \\
\hline
\end{tabular}




\section{Nitrogen a T MID-WINTER}

In split-plot design, nitrogen when applied 6 to 8 weeks before greenfeed is required for grazing gave good responses in grass growth (Table 4). These were 31, 11, and $28 \mathrm{~kg}$ dry herbage/kg N, respectively, in 1968, 1969, and 1970.

TABLE 4: WAIRAU LUCERNE ON EYRE SOIL OVERDRILLED WITH 'GRASSLANDS TAMA' WESTERWOLDS RYEGRASS EFFECTS OF TWO LEVELS OF NITROGEN, APPLIED MID-WINTER (Annual dry herbage yield $\mathrm{kg} / \mathrm{ha}$ )

\begin{tabular}{|c|c|c|c|c|c|c|c|}
\hline & & & & Lucerne & Tama & Unsown & Total \\
\hline \multicolumn{8}{|l|}{ 1968: } \\
\hline Nil & & & & 3,030 & 620 & 670 & 4,320 \\
\hline 22.4 & $\mathrm{~kg}$ & N/ha & $\ldots$ & $\begin{array}{r}3,180 \\
d 0.05\end{array}$ & $2^{1,310}$ & 500 & 4,990 \\
\hline \multicolumn{8}{|l|}{ 1969: } \\
\hline Nil & ;..' & & "1 & 1,400 & 1,370 & 170 & 2,940 \\
\hline 22.4 & $\mathrm{~kg}$ & N/ha & $\ldots$ & ,470 & 1,610 & 340 & 3,420 \\
\hline \multicolumn{8}{|l|}{ 1970: } \\
\hline Nil & & & & 2,400 & 990 & 450 & 3,840 \\
\hline 22.4 & $\mathrm{~kg}$ & N/ha & $\ldots$ & 2,360 & 1,620 & 710 & 4,690 \\
\hline \multicolumn{8}{|c|}{$d 0.05-722$} \\
\hline
\end{tabular}

\section{Utilization of a Lucerne SWARd OVERDRILled}

W I T h TAMA RYEgRASS

To some extent utilization of Tama must' conflict with the optimum requirements for growth of the lucerne crop. This is because lucerne growth will be affected by early spring grazing. Tama shows good recovery from winter grazing and this is illustrated in Table 5, where only lucerne yield was affected.

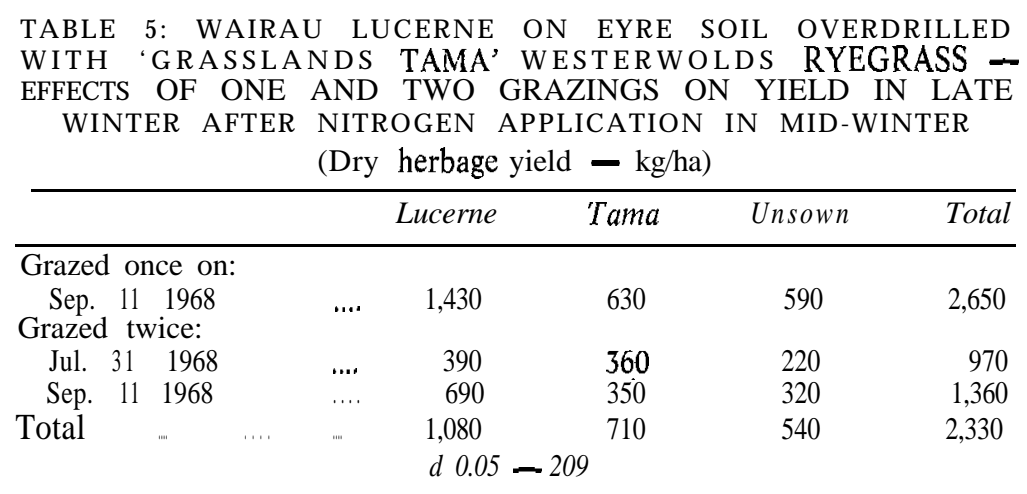


In 1971, two systems of utilization of luceme overdrilled with Tama have been studied: (1) Rotational 4-paddock grazing over the month prior to and succeeding lambing on September. 15, and (2), 2-paddock break-grazing for the month prior to lambing and set-stocking thereafter. By lambing, one cycle of rotational grazing in system 1 had been completed; half of the total area in system 2 had been break-grazed. A second cycle of grazing on regrowth followed for the rotational system. The remainder of the 2-paddock system was set-stocked. Both treatments were stocked at 15 ewes/ha on August 15. The overdrilled area represented the one-third of an all-lucerne farm, which would be spelled from grazing from March until utilized from mid-August. Up to lambing rotationally grazed stock were fed hay ad lib. for the last 2 of 7 days in each paddock; breakgrazed stock were fed hay ad lib. each day.

Table 6 shows that the rotational grazing system enabled considerable savings in hay (and in labour for feeding out) without prejudicing animal performance. This result was obtained in a particularly dry spring when regrowth following grazing was less than normally expected. Even so, stock were able to be re-

TABLE 6: WAIRALJ LUCERNE ON EYRE SOIL OVERDRILLED WITH 'GRASSLANDS TAMA' WESTERWOLDS RYEGRASS

Sum of dry herbage periodically available to 6 ewes/treatment (kg/week), hay fed and animal performance.

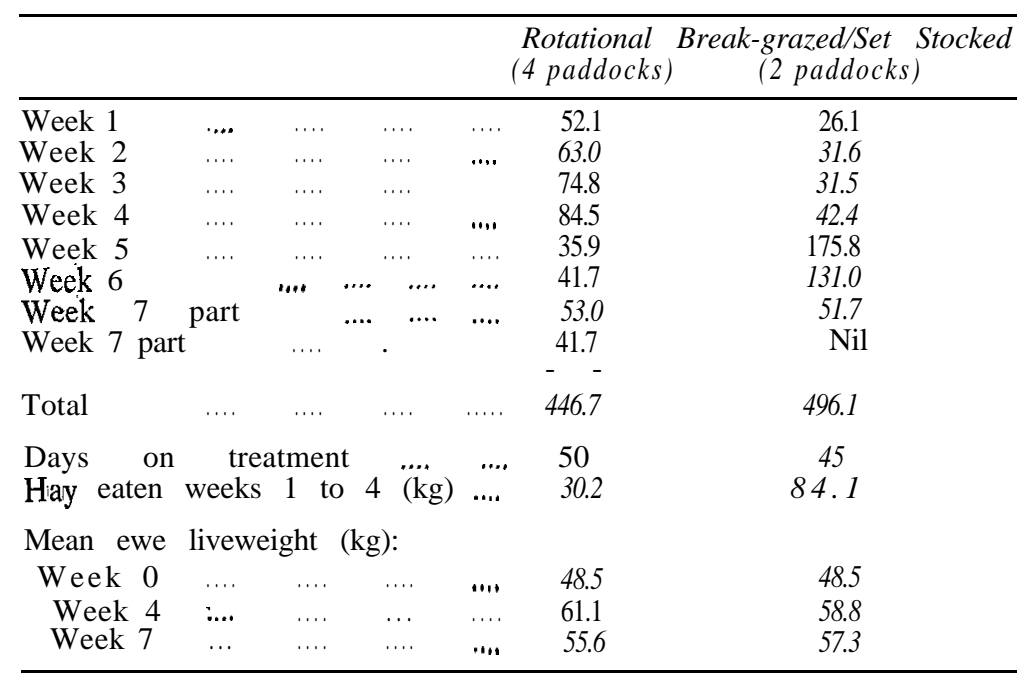


tained for 5 days longer on the rotational system before moving to pure lucerne elsewhere. This result is particularly important because pure lucerne would benefit from the delay in first spring grazing, both in terms of current yield and subsequent rate of regrowth.

\section{HEAVY LANDS}

There has been considerable experimentation with perennial grasses overdrilled into lucerne on heavy lands at and near Lincoln (O'Connor, 1967; Vartha, unpubl. data), but not with Tama.

The chief feature of overdrilling on these soils has been the interspecific competition from autumn growth of lucerne affecting the establishment of grass. This is less of a problem on the light lands. Effects of autumn management on establishment of Tama are shown in Table 7 . Yield of ryegrass grown in cool season was considerably higher where lucerne was cut early in autumn to reduce interspecific competition, and there was only a slight reduction in the total herbage yield of lucerne over autumn and winter. Overdrilling with Tama Increased total dry herbage yields.

TABLE 7: WAIRAU LUCERNE ON WAKANUI SOIL OVERDRILLED WITH 'GRASSLANDS TAMA' WESTERWOLDS RYEGRASS EFFECT OF TIME OF CUTTING IN AUTUMN

(Dry herbage yield $-\mathrm{kg} / \mathrm{ha}$ )

Not 0 verdrilled

Lucerne Tama Unsown Total Lucerne Unsown Total

\section{EARLY CUTTING}

April 16

August 30

\begin{tabular}{|c|c|}
\hline \multicolumn{2}{|c|}{ Not dissected } \\
\hline 560 & 2,570 \\
\hline
\end{tabular}

LATER CUTTING

May 12

August 30

\begin{tabular}{ccrrrrr}
\multicolumn{2}{c}{ Not dissected } & 1,650 & Not dissected & 1,590 \\
270 & 1,640 & 150 & 2,060 & 1,190 & 470 & 1,660
\end{tabular}

Yields of dry herbage of Tama overdrilled into lucerne on Wakanui silt loam in 1971 were $2,570 \mathrm{~kg} / \mathrm{ha}$ in cool season and $1,190 \mathrm{~kg} / \mathrm{ha}$ in warm season. Yields of this grass sown pure on cultivated Wakanui silt loam have ranged from 2,450 to 6,500 $\mathrm{kg} / \mathrm{ha}$ in cool season and 4,000 to $5,830 \mathrm{~kg} / \mathrm{ha}$ in warm season, or 71 to $228 \%$ more herbagc in total for cool and warm season than where it was overdrilled as above. 
Both on droughty and moisture-retentive soils in Canterbury, irrigation can provide considerable increases in lucerne yields. Probably it could also be used to ensure establishment of overdrilled Tama. However, yields from overdrilling would probably be considerably less than where the grass is sown in cultivated soil, Decisions on whether to overdrill Tama seed and the total area of lucerne to overdrill, or whether to grow this grass as a crop on cultivated soil, and at what stocking rates, may possibly be aided by further experimental work guided by simulation studies. Such work has been commenced by the Farm Management Department of Lincoln College.

With present low prices for sheep production, coupled with the current sequence of dry seasons, financial returns from light land farming in Canterbury have become marginal. High costs for protracted feeding of dry supplementary materials, with consequent heavy labour demand, have created a real need for a lower cost, lower labour-demanding system where high stocking rate on all-lucerne is practised. Overdrilling lucerne with Tama ryegrass and rotational grazing of this crop seems capable of fulfilling this need.

Currently, experimental work at Lincoln by Applied Biochemistry and Grasslands Divisioas of DSIR is showing that irrigated lucerne on medium-heavy, moisture-retentive soil under a 5-week harvesting rotation, producing about $18,000 \mathrm{~kg}$ dry herbage/ha, can yield $1,800 \mathrm{~kg} / \mathrm{ha}$ of crude protein extracted by the standard I.B.P. methods (R. M. Allison and E. W. Vartha, unpublished data). Even higher annual yields of dry herbage are being obtained when the crop is grazed by sheep at S-week intervals, but the yield of animal protein from plant protein grown sy that crop is only about $10 \%$ of that which can be extracted by mechanical means. The residue from the extraction is a potentially valuable food for ruminants (Vartha and Allison,. 197 1). The same efficiency of mechanical protein extraction and usefulness of residues applies to Tama ryegrass (Allison and Vartha, unpublished). Future farming systems on light lands in Canterbury will probably involve combinatiaas of the practices. mentioned in this paper to regain acceptable levels of farm financial returns.

\section{A CKN OWLEDGEMENTS}

The assistance of S. J. Rae, T. Fraser and L. R. Fletcher with field work and Mrs C. Purdie and Miss D. Beer with herbage 
laboratory work; Professor J. D. Stewart and "Ashley Dene" Farm Managers R. Rollinson and in particular the late R. Nicholl for provision of facilities and discussion.

\section{REFERENCES}

O'Connor, K. F., 1967: In The Langer, A. H. Reed, Wellington.

Crop: 47-61; 163-176, Ed. R. H. M. O'Connor, K. F.; Vartha, E. W.; Belcher, R. A.; Coulter, J. D., 1968: Proc, N.Z. Grassld Ass., 30: 50-63.

Vartha, E. W., 1967: In The Lucerne Crop: 177-185. Ed. R. H. M. Langer, A. H. Reed, Wellington. wells.

1971: In Lea/ Protein for Human Use. Ed. N. W. Pirie, BlackVartha, E. W.; Allison, R. M., 1971: Proc. N.Z. Soc. Anim. Prod., 31: 64.

\section{DISCUSSION}

Asked by Lynch (Ruakura) if there had been any subsequent effect on lucerne from overdrilling Tam", Vartha stated there had been no measurements made as yet. However, there was much less weed in the area overdrilled, which would mean much less weed control. Mitchell (Palmerston North) inquired if applied nitrogen had increased Tama yields and Vartha replied that the results had been variable $\rightarrow$ from $10 \mathrm{lb} \mathrm{DM} / \mathrm{lb} \mathrm{N}$ up to $30 \mathrm{lb} \mathrm{DM} / \mathrm{lb} \mathrm{N}$. The behaviour of Tama in Canterbury was entirely as an annual. Elliott (Ruakura) commented that results locally with Tama confirmed Vartha's findings, especially for weed control. White (Lincoln College) asked if, in view of Canterbury's unreliable autumn, his results could be repeated with confidence. Vartha agreed that this was a real problem and that the yield then would probably be of the order of $1,500 \mathrm{lb} \mathrm{DM} /$ acre. Douglas (Ruakura) commented that in North Otago cereals had proved more drought resistant than Tama. Vartha said that oats had been tried at Lincoln and that they had given much earlier feed. However, there was the very serious problem of barley yellow dwarf virus. He thought that ryecorn might be better in North Otago, but there would be an additional cost of seed. Gordon (Taupo) suggested that perhaps the first cut in spring could be ensiled but Vartha considered that such a high quality feed as Tama should be grazed, thus avoiding the losses associated with silage. 